\title{
Who does SEO in Spain? A cybermetric methodology for the construction of company universes
}

\author{
Raquel Escandell-Poveda; Mar Iglesias-García; Natalia Papí-Gálvez
}

Nota: Este artículo se puede leer en español en:

http://www.profesionaldelainformacion.com/contenidos/2021/may/escandell-iglesias-papi_es.pdf

Cómo citar este artículo:

Escandell-Poveda, Raquel; Iglesias-García, Mar; Papí-Gálvez, Natalia (2021). "Who does SEO in Spain? A cybermetric methodology for the construction of company universes". Profesional de la información, v. 30, n. 4, e300419.

https://doi.org/10.3145/epi.2021.jul.19

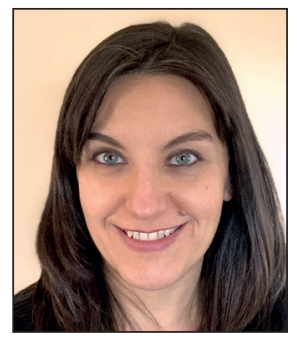

Raquel Escandell-Poveda $\bowtie$ https://orcid.org/0000-0002-8398-1873

Universidad de Alicante

Campus Sant Vicent del Raspeig, Ap. 99. 03080 Alicante, Spain

r.escandell@ua.es

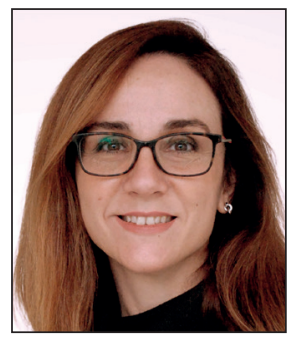

Natalia Papí-Gálvez

https://orcid.org/0000-0002-4871-1691

Universidad de Alicante

Campus Sant Vicent del Raspeig, Ap. 99.

03080 Alicante, Spain

natalia.p@ua.es

Manuscript received on January $10^{\text {th }} 2021$ Approved on February $26^{\text {th }} 2021$

\section{Abstract}

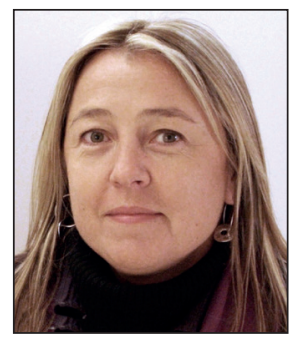

Mar Iglesias-García

https://orcid.org/0000-0001-7926-5746

Universidad de Alicante

Campus Sant Vicent del Raspeig, Ap. 99.

03080 Alicante, Spain

mar.iglesias@ua.es

Due to their widespread use, search engines, and specifically Google, are extremely important to attract qualified traffic and thereby achieve the commercial objectives of corporations. Search engine optimization (SEO) allows enhanced connection of corporate websites with their audiences through search engines, using certain keywords. This study describes a methodology to determine the most important Spanish companies offering SEO services to third parties, representing an exploratory study of applied cybermetrics for the construction of a universe of companies. One of the relevant results of this work is the design of an information retrieval strategy based on a statistical analysis of search terms and the performance of geolocated searches in all the provincial capitals and Spanish cities with more than 100,000 inhabitants. After cleaning and reviewing the unique URLs, it is concluded that there are 1,043 companies offering SEO services in Spain positioned in Google. These are basically companies with more than one person, operating from a single location, and that offer other services in their portfolio together with SEO. In addition to providing a starting point for future research on the SEO sector in Spain, this research proposes a methodology for the creation of study universes of brands or companies.

\section{Keywords}

Search engine optimization; SEO; Web positioning; Search engines; Google; Information retrieval strategy; Search engine optimizer; SEO industry; SEO consultants; SEO companies; SEO agencies; Visibility; Cybermetrics; Universe of companies.

Funding

This work is linked to the project "Interactive narration and digital visibility in interactive documentaries and structured journalism" ["Narración interactiva y visibilidad digital en el documental interactivo y el periodismo estructurado”], RTI2018-095714-B-C21 (Micinn/Feder), Ministerio de Ciencia, Innovación y Universidades, Spain. 


\section{Introduction}

Google, the most widely used search engine in the world with a 92.6\% market share (Fernández, 2021), processes more than 3,500 million searches daily (Internet Live Stats, 2021). In Spain, 82.8\% of the population uses the internet (AIMC, 2021), of which $88 \%$ use search engines daily (Fernández, 2021). These figures reveal their importance as an entry channel to achieve the objectives of online web presence, the need to obtain the top positions to increase visibility (Azzopardi et al., 2020), and the possibility of connecting with audiences and attracting customers (Pack-Sheffield, 2020). The discipline of SEO is responsible for all of this, also being known as web positioning.

This study focuses on the creation of a universe of companies in the market sector that offers SEO services in Spain. A methodology to identify and quantify the best-positioned SEO companies, agencies, or consultancies in local searches is presented as a first step to determine the size and characteristics of this industry. Companies that offer SEO to third parties are studied, thus excluding both people employed within such companies who exercise web positioning functions, called in-house SEO, as well as those who apply these techniques in their own projects (Maciá-Domene, 2020).

\subsection{Conceptualization}

Cybermetrics is the

"discipline dedicated to the quantitative description of the content and communication processes that occur in cyberspace" (Aguillo, 2005).

It is also known as webometrics (or webmetrics) when it focuses on the study of the content, link structure, and search engines on the web (Almind; Ingwersen, 1997; Björneborn; Ingwersen, 2001). The use of one term or another has been the subject of debate in the scientific literature, although the use of the former is more widespread in Spain, despite being less specific (Orduña-Malea; Aguillo, 2014).

The earliest investigations related to this discipline focused on the impact and relationship between links and the analysis of search engine results (Arroyo-Vázquez et al., 2005; Thelwall, 2009; 2010). In its beginnings, cybermetrics was also used to study the size of the web (Lawrence; Giles, 1998; Kazon, 2003) and has also been applied for the analysis of citations, co-citations, and co-occurrence of words (Larson, 1996; Thelwall; Wilkinson, 2004). Regarding the relationship between cybermetrics and SEO, search engine positioning is seen as a formal cybermetric indicator, which makes "reference to the quantification of formal aspects of company websites" (Orduña-Malea; Aguillo, 2014, p. 111).

SEO is also understood as website optimization for search engines (IAB Spain, 2010) or, more simply, as search engine positioning (Gonzalo-Penela, 2004; Arbildi-Larreina, 2005; Rovira et al., 2010; Vállez et al., 2010; Soler-del-Pozo, 2012; Serrano-Cobos, 2014) or web positioning (Codina, 2004; Soltero-Domingo; Bodas-Sagi, 2005; Moreno-Pelayo, 2005; Marcos; Codina, 2005; Marcos et al., 2006; Valdés-Morris, 2007; Rovira, 2008; Rovira; Codina; Marcos, 2009; Morato-Lara et al., 2013; Moráguez-Bergues; Perurena-Cancio, 2014; Iglesias-García; Codina, 2016). One can also refer to a search engine optimizer (Soltero-Domingo; Bodas-Sagi, 2005; IAB Spain, 2010; Papí-Gálvez; López-Berna, 2011) as a person who performs or applies SEO techniques. Its meaning depends on the context, although if there is a possibility of confusion, when SEO is mentioned as a professional profile, additional terms such as expert, consultant, specialist, manager, or professional can be added.

In the scientific literature, the definition of SEO departs from qualifying it as a discipline, process, strategy, or set of professional or practical activities (Marcos; Codina, 2005; Weideman, 2009; Álamo-Álvarez, 2010; Moráguez-Bergues; Perurena-Cancio, 2014; Enge et al. 2012; Gonzalo-Penela, 2015; Iglesias-García; Codina, 2016; Pérez-Montoro, 2016). Many authors also mention the study of the operation of search engines as the main part of the definition (Pérez-Montoro, 2016) or "the importance criteria of web pages" (Gonzalo-Penela, 2015, p. 5); that is, they start from an initial analysis of how search engines work and which factors they take into account to achieve positioning, before the application of the techniques themselves.

In continuation, the definition alludes to the main objective of SEO, that is, obtaining good positioning for or improving the visibility of a website in searches with respect to their competition. Some authors also highlight other nuances such as the absence of payment to the search engine to improve such positions (Kritzinger;

\section{The consideration of SEO as a method to achieve the objectives of a site highlights the need to integrate it into the business and communication strategy}

Weideman, 2014; Iglesias-García; Codina, 2016; Chen et al., 2011) or add the final objective of achieving this visibility, i.e., the attraction of traffic (Enge et al., 2012; Mavridis; Symeonidis, 2015).

This analysis of the meanings proposed by authors and organizations allows the definition of SEO to be broken down into three fundamental aspects:

1. The nature of SEO: a discipline, set of activities, process, technique, strategy, etc.

2. The aim of SEO: understanding search engines, improving the position of a website when faced with a relevant query, and capturing effective traffic to achieve objectives

3. The implementation of SEO: using techniques both on and off the website 
All this provides a complete vision of SEO that can be synthesized as follows: a discipline that is based on the operation of search engines to improve the positioning of a website in organic results in the face of searches from their potential audience by applying various techniques both within as well as outside the website to attract effective traffic that contributes to the fulfillment of its objectives.

This consideration of SEO as a method to achieve the objectives of a website highlights the need to integrate it into the business and communication strategy (IAB Spain, 2010; Baye; De-Los-Santos; Wildenbeest, 2016), understanding the search engine as a channel through which to reach a series of audience segments (Serrano-Cobos, 2015). The ultimate goal of the SEO process is not to appear in the best positions of a search engine but rather to connect with the audience of the company or institution to which the web belongs (Solís, 2016).

The SEO activity thus represents an audience analysis (Killoran, 2009): it is based on knowing which people have visited the client's website, which ones should do so, which keywords (search expressions) will lead the correct people to the correct sites, and how to connect customers with the services that are right for them.

\subsection{Factors and types}

Over the years, various studies in the scientific literature have tried to establish which are the SEO factors or most important criteria required to achieve better positioning, or have focused on testing the effectiveness of some of them, including both Spanish (Codina; 2004; Cueto-Álvarez-de-Sotomayor et al., 2005; Soltero-Domingo; Bodas-Sagi, 2005; Morato-Lara et al., 2005; Moreno-Pelayo, 2005; Arbildi-Larreina, 2005; Marcos; Codina, 2005; Marcos et al., 2006; Sabaté-Garriga et al., 2009; Rovira et al., 2010; Soler-del-Pozo, 2012; Morato-Lara et al., 2013; Lopezosa; Codina; Freixa, 2018; Lopezosa; Codina; Gonzalo-Penela, 2019) and international works (Zhang; Dimitroff, 2005; Fortunato et al., 2005; Evans, 2007; Vaughan; Zhang, 2007; Su et al., 2010; Killoran, 2010; Zhu; Wu, 2011; Egri; Bayrak, 2014; Mavridis; Symeonidis, 2015; Chotikitpat; Nilsook; Sodsee, 2015; Zhang; Cabage, 2017; Özkan et al., 2019).

The prominent factors considered in these investigations include inbound links, keyword density and use, content quality, authority and trust, technical aspects of the website, or user satisfaction factors such as length of stay.

Given the speed with which search algorithms are modified (Wahba; Barhoom, 2019), focusing on Google due to its near monopoly in the sector, beyond looking for specific factors that may become obsolete over time, SEO establishes classifications that combine its various aspects. One of the most common is to take into account where such techniques are applied by dividing it into SEO on page/site versus off page/site, depending on whether they are applied on the website itself or outside of it, respectively (IAB Spain, 2010; Rovira et al., 2010; Serrano-Cobos, 2015; Gonzalo-Penela, 2015; Chotikitpat; Nilsook; Sodsee, 2015; Matošević, 2015; Özkan et al., 2020).

In turn, within on-page SEO, there are two main areas: technical SEO and content SEO. The purpose of the former is to improve the indexability and traceability of the site (Solís, 2017), and it requires certain knowledge of programming and web development (Codina et al., 2017; Krstić, 2019). Meanwhile, content SEO tries to add value by guaranteeing that the texts, images, and videos include relevant and updated information, to improve the relevance of the web with respect to searching (Solís, 2017), and ensure that they reach their potential audience, not only in search engines but also via other digital platforms such as social networks (Lopezosa; Codina; Gonzalo-Penela, 2019).

SEO specialists apply these strategies within companies themselves (in-house SEO) or externally as independent consultants or in agencies. This is a professional role emerging fundamentally from computer science, due to its technical aspects, and, above all, from communication, advertising, and marketing (Miguel-San-Emeterio, 2018; Maciá-Domene, 2020), given its strategic nature in attracting potential audiences and generating results for the company.

SEO is also an industry that, in the USA alone, generates an estimated annual income of 80 billion dollars (McCue, 2018), and organizations such as the now-defunct Search Engine Marketing Professional Organization (Sempo) sought to bring together marketing professionals from search engines worldwide, although no research related to the structure or size of this sector has been found.

This body did not achieve massive penetration in Spain, and there are no other associations of SEO consultants, or references to it as a commercial activity. Only Marketing4Ecommerce, a portal specialized in e-commerce marketing, has produced a ranking of the best SEO agencies in Spain since 2017, which although it serves as a sample of the best-positioned companies in the sector, is a list limited to 60 entities.

Despite this lack of a census or business organization for the industry, the importance of the sector in the country is reflected in the numerous references to the figure of
Although there is no specific directory in Spain of companies dedicated to SEO, the importance of this sector is reflected in the references to the SEO specialist in studies of professional profiles, the training offered, the community that shares knowledge online, and the continuously increasing specialized professional congresses 
SEO specialist in studies on professional profiles (Miguel-San-Emeterio, 2018), the amount of training offered, the large community that shares knowledge online, and the constantly increasing specialized professional congresses (Maciá-Domene, 2016).

\section{Objectives, sources of information, and stages of the method}

The main purpose of this research is to present a methodology for the creation of a universe of companies, taking as a reference the companies that offer SEO in Spain with better local web positioning, thus illustrating the size of the industry and providing an overview of the sector. This objective corresponds to the delineation and quantification stage of a studied population, which is key in social research and, in particular, for research that aims to determine the structure of this sector in depth.

Specifically, this article aims to:

(1) Present the design for a cybermetric methodology including a statistical analysis of query terms as well as the search and information retrieval strategy applied.

(2) Provide basic information on the universe of SEO companies in Spain with the best web positioning, in particular, the size of the business sector, its geographical distribution, the type of company, the relevance of the SEO service, and the ranking of the best-positioned websites of SEO companies for local searches in provincial capitals and cities with more than 100,000 inhabitants.

To achieve these aims, an exploratory study is carried out, starting with the selection of resources from official and unofficial sources, statistics, and professionals, such as: the Instituto Nacional de Estadística (INE, National Institute for Statistics), the Sistema de Análisis de Balances Ibéricos (SABI, Iberian Balance Sheet Analysis System), or the directories of professional associations related to advertising, and including an applied cybermetric analysis based on Google Search as a source and the formal indicator of web positioning.

The delineation and quantification of the universe are carried out in two stages. On the one hand, the presence or absence of SEO as an economic activity is confirmed using the latest (2009) version of the Clasificación Nacional de Actividades Económicas (CNAE, Spanish National Classification of Economic Activities). The CNAE of the INE offers a catalog of activities that companies can carry out and thus enables a determination of the number of companies carrying out a given activity in Spain. Furthermore, the CNAE is, in turn, based on the Nomenclatura Estadística de Actividades Económicas de la Comunidad Europea (NACE, Statistical Nomenclature of Economic Activities of the European Community) and is thus harmonized internationally.

The nomenclature of the headings and areas of activity available on the INE website were assessed in detail to determine whether any of them could correspond to, or include, SEO companies. To confirm whether the companies that offer SEO are included in any of these areas of activity, the SABI database, which contains information on the business sector over three decades, was also consulted.

In addition, a selection of professional associations related to communication, advertising, and digital marketing was reviewed to determine whether they offer a directory specialized in SEO. The websites of the organizations included in the technical committee of InfoAdex, a benchmark study on advertising investment in Spain, were thus explored. This committee comprises the most important advertising and media associations: the Asociación de Agencias de Medios (AM, Association of Media Agencies, 2020), Asociación Española de Agencias de Comunicación Publicitaria (AEACP, Spanish Association of Advertising Communication Agencies, 2020), Federación de Empresas de Publicidad y Comunicación (La Fede, Federation of Advertising Communication Agencies), Interactive Advertising Bureau Spain (IAB Spain, 2020), and Asociación Española de la Economía Digital (Adigital, Spanish Association of the Digital Economy, 2020). The Asociación Española de Agencias Digitales (Spanish Association of Digital Agencies) was also included in this exercise.

Finally, given the meager results obtained in this stage, a specific study was designed, focused on the Google search engine as a source of information, to extract the main data relating to the SEO sector in Spain and achieve the aims of this research. As a complement, other resources have been used, such as Ahrefs SEO, the Searcher website, and functions of the Google Chrome browser, such as private browsing, the Sensors geolocation emulator, or the Oscraper extension.

The information retrieval strategy includes geolocated searches in provincial capitals and cities with more than 100,000 inhabitants. After extracting and cleaning the identified websites, the geographical distribution of the SEO companies was noted, identifying the cities in which they were located, both their headquarters and branches, using the data included in the contact section and/or related to the ownership of the web as indicated in the legal notice.

Meanwhile, by consulting each website, they were also classified according to whether they were companies corresponding to independent professionals or having more than one person, based on the content included in the home page, the "about me/us" page, or similar. Finally, for each company, the importance given to SEO as a service was analyzed. This information was collected by inspecting the home page, menu, and/or internal sections. Depending on whether SEO appeared alone or with other services, it was defined as unique or not. When it appeared accompanied by other services, it was determined whether they were all at the same level or if SEO stood out as the main service by having more content, more associated subservices, or more space dedicated. 
The searches resulting from the application of the proposed design were carried out between 6 and 22 February 2019. The results of these searches were verified and updated at a later stage, between January and March 2020. In this second period, companies were contacted to clean the database by eliminating nonexistent websites. Likewise, companies that no longer offered SEO services and those that belonged to the same company were excluded.

The most relevant findings of the sources consulted and of the strategy applied are presented below. The results include the design of the study carried out with the Google search engine, with sufficient detail to facilitate the reproducibility of the method and thereby guarantee both its verification and application in any future study, as well as its updating.

\section{Results}

\subsection{SEO companies in the classification of economic activities and professional associations}

The review of all the codes proposed in CNAE-2009 revealed that no specific activity referred to SEO, optimization for search engine positioning, or any of its possible variants, thus eight headings were identified, divided into two main areas, that could include companies that offer SEO services: (1) information and communications, and (2) professional, scientific, and technical activities. Within the former, four headings closest to SEO were identified: computer programming activities, other services related to information and computer technologies, data processing, hosting and related activities, and web portals. On the other hand, in the latter area, four other headings under which SEO companies could be framed were identified: public relations and communication, other business management consulting activities, advertising agencies, and other professional, scientific, and technical activities-not otherwise specified.

Once the headings had been identified, 81,400 registered companies were obtained by filtering the $S A B I$ database using the selected CNAE codes. To limit the number of records to be analyzed, as a test, the search was limited to the Province of Alicante. This query resulted in 2,165 companies, whose description in the database was reviewed, as well as their website in case of doubt regarding their activity. The conclusion was that, although SEO companies could be found under all of the headings except for two ("Other business management consulting activities" and "Other professional, scientific, and technical activities-not otherwise specified"), these also contain other types of entities, which is why this approach was rejected as a means of accessing knowledge regarding the SEO sector.

Based on the study of the directories of professional associations, the AM, AEACP, and La Fede were also discarded because their members are advertising agencies without any specific grouping related to SEO.

In the case of IAB Spain, the "Who's who" section classifies its associates by their activity sector, none of them being SEO. In addition, when searched using the other option, i.e., with tags, and with the keywords of SEO, positioning, or search engines, a maximum of only six companies appeared, so it was also discarded.

Meanwhile, Adigital includes "more than 500 companies (...) related to activity in the digital economic in Spain" (Adigital, 2020). However, it is not possible to use its website to search for members by type of activity.

The other business organization likely to group SEO companies, the Asociación Española de Agencias Digitales (Spanish Association of Digital Agencies), has 45 members according to its members page, but a random visit to the websites of some revealed that many of them do not offer SEO services.

After this first stage and given that no specific directory of companies dedicated to SEO was identified, it was decided to create a universe of companies by using Google (the main channel in which this type of company applies its strategies) as a source, and positioning in geolocated searches as a formal quantification indicator.

\subsection{Proposal for an information retrieval strategy using Google}

To search for companies that offer SEO in Spain with better web positioning in local searches, one must first determine the related keywords that are most used in Google. This statistical analysis was carried out using the Ahrefs tool, which allows the determination and comparison of search volumes for different concepts or phrases. After investigating and comparing the terms that could be used to search for this type of company and professional, it was concluded that the most relevant, with 100 or more monthly searches on Google.es, were: "agencia seo" (SEO agency, 800), "consultor seo" (SEO consultant, 600), "empresa seo" (SEO company, 150), "consultoria seo" (without an accent, SEO consultancy, 150), and "experto seo" (SEO expert, 100). These search strings were used to construct the universe of better-positioned companies that offer SEO services in Spain, to which we added "seo consultora" (SEO consultant), because it is the female version of SEO consultant (the second most searched term) in Spanish and, in addition, a polysemic word that can also refer to a company. The list is completed with others such as: "freelance seo" (SEO freelancer), "consultoría seo" (SEO

Companies that offer SEO to third parties are present in practically all the provinces of Spain, with Madrid, Barcelona, and Valencia being the cities that stand out the most. However, it is notable that the SEO companies that are best positioned in Google are not always located in large capitals consultancy), and "profesional seo" (SEO professional). 
The first part of the search consisted of determining the first 20 Google results for these terms in Spain, corresponding to the first two pages of Google.es, using the Ahrefs tool. Although only $0.78 \%$ of users consult the results of the second page (Dean, 2019), it was included in this research to minimize the fluctuation bias found when using a search engine for cybermetric analysis (Bar-Ilan, 1999; Ingwersen, 1998; Mettrop; Nieuwenhuysen, 2001; Rousseau, 1999; Snyder; Rosenbaum, 1999; Orduña-Malea; Aguillo, 2014).

To expand the search to local companies and professionals throughout Spain, search strings were constructed by adding the name of all the provincial capitals plus cities with more than 100,000 inhabitants, according to the latest published ongoing local census of the INE (2018). The resulting terms for this second part of the search are:

- seo agencia + city name (e.g., seo agencia madrid)

- consultor seo + nombre de ciudad (e.g., consultor seo madrid)

- empresa seo + nombre de ciudad (e.g., empresa seo madrid)

- consultoria seo + nombre de ciudad (e.g., consultoria seo madrid)

- consultora seo + nombre de ciudad (e.g., consultora seo madrid)

- experto seo + nombre de ciudad (e.g., experto seo madrid)

For cities with two names (in Spanish and another co-official language), we used that which was most searched for in Spain according to Ahrefs. For compound placenames, such as Castellón de la Plana, Las Palmas de Gran Canaria, Santa Cruz de Tenerife, and Palma de Mallorca, the simple name was used.

To eliminate the geographic bias resulting from the location where the query was carried out, the search string also included the UULE code, the parameter used by Google to geolocate searches, applying a local internet protocol (IP) address. The results obtained from a specific city can thus be emulated without physically traveling to each one considered in this study. The UULE codes for each city were extracted using the Isearchfrom website (Figure 1), which allows geolocated searches to be carried out. When making a query using this tool, specifying a specific city, the UULE code corresponding to that city appears in the URL (Annex 2).

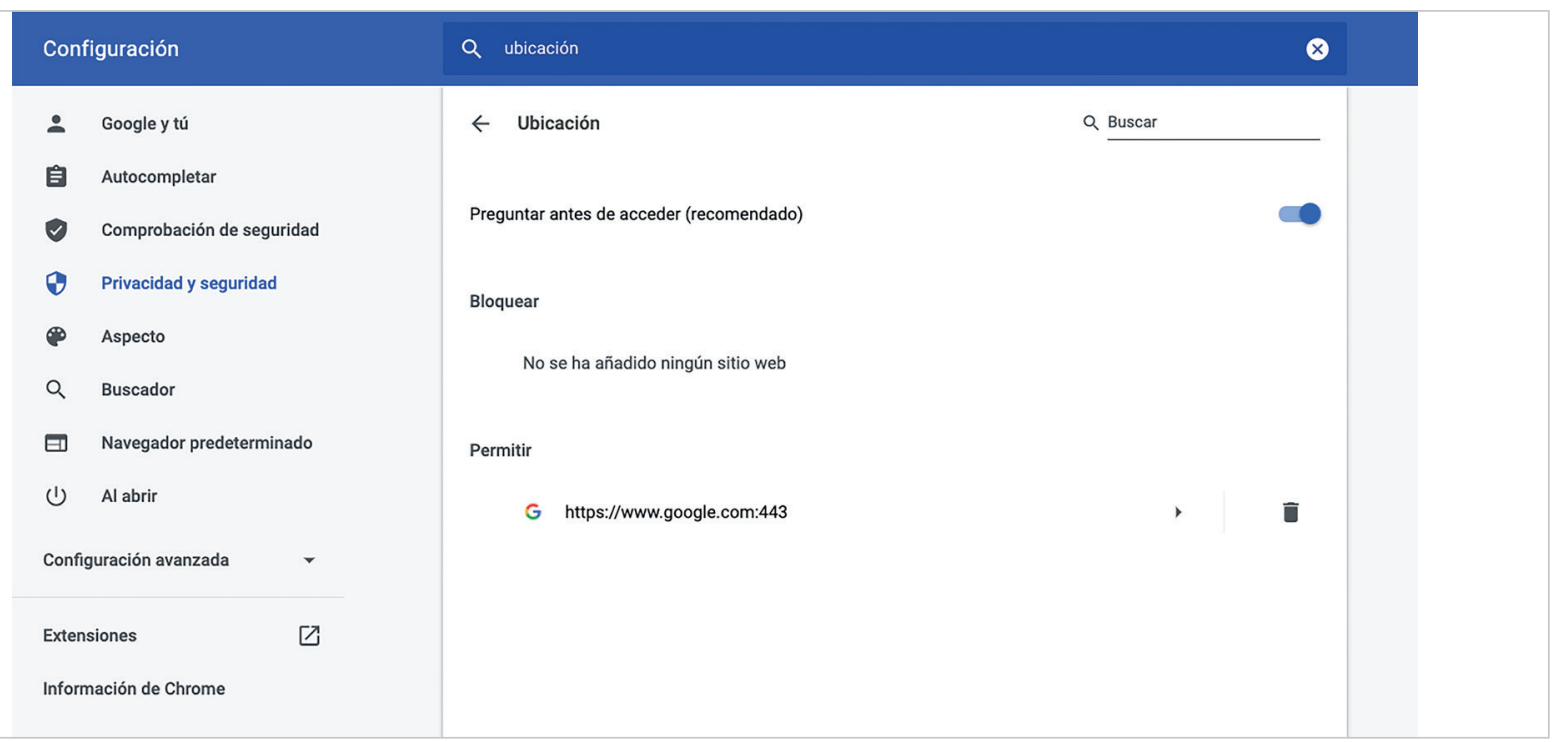

Figure 2. Detail of the configuration window to permit websites to know your location. Google Chrome browser 
For several cities for which the UULE parameter could not be extracted through the Isearchfrom website, the Sensors functionality of Google Chrome was used. The steps to achieve this are the following:

- The search engine is allowed to access the location using the option "Configuración > Configuración Avanzada > Configuración de Contenido > Ubicación" [Settings > Advanced $>$ Content settings $>$ Location] (Figure 2).

- The latitude and longitude coordinates of the desired city are changed using "Herramientas para desarrolladores > Sensors" [Tools for developers > Sensors] (Figure 3).

Finally, possible biases produced by cookies or browser history were eliminated by using incognito mode, as well as setting the parameter "pws $=0$ " to disable personalization of the search results. Despite the use of these two methods, it should be borne in mind that one can never achieve $100 \%$ search neutrality.

The queries were made using the desktop version of the Google Chrome browser using the URLs with the different parameters. As an example, the URL of the search for "agencia seo madrid" (SEO agencies in Madrid) is as follows: www.google.es/search?q=agencia\%20seo\%20madrid\&uule $=w+C A I Q I C l g T W F k c m I k L E N v b W 11 b m I 0 e S B V Z i B N Y W R y a W$ QsU3BhaW4\&pws=0\&num $=20$

This search URL can be broken down as follows:

- www.google.es/search?: The Google Spain website with the search parameter

- q=agencia\%20seo\%20madrid: The search string (with spaces replaced by "\%20")

- uule=w+CAIQICIgTWFkcmlkLENvbW11bmIOeSBvZiBNYWRyaWQsU3BhaW4: the UULE code (an IP geolocalized to Madrid in this case)

- pws = 0: the code for depersonalization of the results

- num $=20$ : a code so that 20 results appear on the page instead of 10 .

From each page of results thus obtained, the URLs of the 20 organic results were downloaded, taking into account only the root domain (without extensions of internal pages), using the Oscraper plugin to automate the process.

To form a summary, the six most relevant (by search volume) terms related to SEO companies were selected, and the Ahrefs tool was used to extract the first 20 results for each in Google Spain. Additionally, the names of provincial capitals (54) and cities with more than 100,000 inhabitants in Spain (27) were added to these terms, with six combinations for each location. Geolocated search URLs were created by city for each of these six combinations, resulting in a total of 492 searches (Table 1).

Table 1. Synoptic table of the methodology

\begin{tabular}{|c|c|}
\hline Initial search date & Between 6 and 22 February 2019 \\
\hline \multicolumn{2}{|l|}{ Search terms: } \\
\hline In Ahrefs for Google Spain (without placename) & $\begin{array}{l}\text { Six search strings } \\
\text { agencia seo } \\
\text { empresa seo } \\
\text { consultoria seo (without an accent) } \\
\text { consultor seo } \\
\text { consultora seo } \\
\text { experto seo }\end{array}$ \\
\hline $\begin{array}{l}\text { In Google Spain: geolocated searches adding the name of the city, e.g., } \\
\text { agencia seo madrid (with the browser geolocalized in Madrid) }\end{array}$ & $\begin{array}{l}\text { Six search strings combined: } \\
\text { agencia seo + ciudad } \\
\text { empresa seo + ciudad } \\
\text { consultoria seo + ciudad (without an accent) } \\
\text { consultor seo + ciudad } \\
\text { consultora seo + ciudad } \\
\text { experto seo + ciudad }\end{array}$ \\
\hline $\begin{array}{l}\text { Cities from which the searches were carried out with the name inclu- } \\
\text { ded in the search string }\end{array}$ & $\begin{array}{l}82 \text { cities: } \\
\text { - All provincial capitals: } 54 \text {. } \\
\text { - All cities with more than 100,000 inhabitants that are not provincial } \\
\text { capitals: } 27 \\
\text { - } 1 \text { without specifying the term or location (using Ahrefs) } \\
54+27+1=82\end{array}$ \\
\hline Number of searches performed & $\begin{array}{l}492 \text { searches: } \\
6 \text { search strings } \times 82 \text { cities }=492\end{array}$ \\
\hline
\end{tabular}




\subsection{Description and quantification of the SEO sector in Spain: cleaning and sizing the SEO industry}

The searches carried out according to the methodology explained above yielded a total of 9,794 URLs. The total should be 9,840 (492 searches $\times 20$ URLs), not counting repetitions, but the number is reduced to 9,794 because:

- In Santa Coloma de Gramenet, there are only 16 results for "consultant seo santa coloma";

- In Córdoba, there are only 19 results for "cordoba seo expert" (without an accent);

- On 32 occasions, one of the results was a video carousel (which were not counted);

- On 9 occasions, one of the results was an image carousel (which were not counted).

From this total, after eliminating duplicates, a total of 1,473 unique URLs remained and were explored completely to eliminate websites that did not correspond to a company or professional offering SEO services in Spain. To carry out this filtering process, the content of the web was reviewed, discarding those that did not meet the following requirements:

- Be a company or professional located in Spain. The appearance of an address in Spain was confirmed by looking at the contact section or exploring the legal notice page. Websites where this information did not appear explicitly were retained in the list provided that: the website was written in Spanish or another co-official language of Spain, or offered services in Spain.

- Offering SEO services. We included the concept with any of its names: SEO, web positioning, Google positioning, or similar. We thus excluded websites of public organizations, job portals, training schools, companies in other countries, personal websites without a commercial purpose, cybermedia, directories, coworking spaces, or ornithology websites (which appear due to the polysemy with the Sociedad Española de Ornitología, SEO, the Spanish Ornithological Society).

We also eliminated URLs belonging to the same company, which were detected by: redirection to another domain name, the same website but with a different top-level domain (e.g., company.es and company.com), or providing the same contact information.

Likewise, personal websites of professionals who, in turn, were responsible for companies whose website already appeared in the list were also discarded.

After this filtering processing, it was established that the size of the universe of companies and professionals that perform SEO in Spain with the best local web positioning is 1,095. In a later stage of the investigation, the total list was refined again and nonexistent websites that no longer offered SEO services or that belonged to the same company were eliminated, representing less than $5 \%$ of the total, a percentage that could be considered acceptable according to the margin of error typically admitted in social research (Ruiz-Olabuénaga; Aristegui; Melgosa, 1998). It was found that most of this error was generated by nonexistent companies (2.6\%), followed by duplicate websites (1.5\%). Finally, it was established that the universe consisted of 1,043 SEO companies (Table 2).

Table 2. Synoptic table with SEO company search results

Number of results obtained and analyzed (the URLs of the results are extracted considering only the main domain, without internal pages, e.g., www.empresa.com and not www.empresa.com/agencia-seo)

\section{9,794 URLs:}

The first 20 organic results for each search (20 URLs in all cases, except those specified below).

Starting from:

6 search strings $\times 82$ locations $\times 20$ results $=9,840$ resulting URLs - In Santa Coloma de Gramenet, there were only 16 results for "consultor seo santa coloma" (4 fewer)

- In Córdoba, there are only 19 results for "cordoba seo expert" (without an accent) (1 fewer)

- On 32 occasions, one of the results was a video carousel (which were not counted)

- On 9 occasions, one of the results was an image carousel (which were not counted)

$9,840-4-1-32-9==9,794$ URLs resulting from all searches 1,473 URLs

Unique URLs after removing duplicates

(1,095 URLs

1,095 URLS

that were not companies or professionals actively offering SEO services.

Total URLs after second cleaning (January-March 2020)

\subsection{Main data related to the SEO sector in Spain}

The companies or professionals that appear most in the results and thus enjoy better positioning and visibility compared with their competitors are presented in Table 3. Among them, the company that appears the most times, specifically 317 times, representing $3 \%$ of occasions when considering the raw results for the 9,794 URLs, is Neoattack, a digital mar- 
keting agency located in Madrid. It is followed, with similar percentages (always above 2\% of searches) by: Webpositer in Alicante, Netbulb social media in Cáceres, Alberto Fernández, a consultant from Madrid, and Centro Seo, a company exclusively offering SEO located in Torrent, Valencia.

Below that 2\% level appear two other consultants, Juan Luis Mora and Fede Gómez, from Badajoz and Toledo, respectively, followed by three other agencies: Agencia SEO in Madrid, focused on this service, Empresa de Servicios Web, with a diversified portfolio, located in Talavera de la Reina (Toledo), and completing the top 10, Campo Semántico, a digital marketing agency with a presence in Madrid and León.

Table 3. Top 10 companies offering SEO in Spain according to their Google positioning

\begin{tabular}{|c|c|c|c|c|}
\hline URL & City & Independent consultant & $\begin{array}{l}\text { Number of times } \\
\text { appearing in the } \\
\text { results }\end{array}$ & $\begin{array}{c}\% \text { of the total }(9,794 \\
\text { results })\end{array}$ \\
\hline neoattack.com & Madrid & - & 317 & 3.2 \\
\hline webpositer.com & Alicante & - & 285 & 2.9 \\
\hline netbulbsocialmedia.com & Cáceres & - & 273 & 2.8 \\
\hline albertofdez.com & Madrid & Yes & 243 & 2.5 \\
\hline centroseo.com & Torrent & - & 234 & 2.4 \\
\hline juanluismora.es & Badajoz & Yes & 185 & 1.9 \\
\hline fedegomez.es & Toledo & Yes & 168 & 1.7 \\
\hline agencyseo.online & Madrid & - & 144 & 1.5 \\
\hline empresadeserviciosweb.com & Talavera de la Reina & - & 119 & 1.2 \\
\hline camposemantico.es & Madrid and León & - & 110 & 1.1 \\
\hline
\end{tabular}

Note: URLs with the most appearances in SEO company search results

Regarding the number of locations identified for the SEO companies found, $89 \%$ were present in only one city, while $8.1 \%$ had several branches. In 3\% of cases, the geographic location was not specified (Table 4).

Regarding the importance of SEO in their portfolio of services, $20.2 \%$ offered SEO exclusively or as their main service, while the remaining $79.9 \%$ presented it as one element of their offering (Table 5).

Regarding size, $79.3 \%$ were agencies or companies with more than one person, while the rest were independent consultants (Table 6).

The geographical distribution by city included 1,164 locations, considering both the headquarters and branches. Among all of these, Madrid was the city with most SEO companies, representing $11.3 \%$ of the total ( $n=132$ ), followed by Barcelona with $6.8 \%(n=79)$ and Valencia with $3.3 \%(n=38)$. After these cities (the three most populous in Spain), the top 10 is completed by Zaragoza, Alicante, Malaga, Seville, Bilbao, and Granada, each with more than 20 SEO companies, plus Toledo with 19 companies (Annex 2). Ávila is the only provincial capital lacking locally positioned SEO companies.

Considering the density of SEO companies per inhabitant, among the mentioned city ranking, Toledo stands out with a ratio of 22.5 companies per 100,000 inhabitants, well above the rest, given that its population does not reach 85,000 . On the other hand, it is worth mentioning Granada and Alicante, with a ratio of more than 8 companies per 100,000 inhabitants. The latter, with 27 companies, is the fifth most important in Spain in terms of the number of SEO companies, having only one fewer than Zaragoza that has twice the population.
Table 4. SEO companies by number of locations

\begin{tabular}{|l|c|c|}
\cline { 2 - 3 } \multicolumn{1}{c|}{} & Frequency & Percentage \\
\hline SEO companies with just one location & 928 & 89 \\
\hline SEO companies present in more than one city & 84 & 8 \\
\hline Location not specified & 31 & 3 \\
\hline & 1,043 & 100 \\
\hline
\end{tabular}

Table 5. SEO companies by the importance they give to it as a service

\begin{tabular}{|l|c|c|}
\cline { 2 - 3 } \multicolumn{1}{c|}{} & Frequency & Percentage \\
\hline SEO is their only service & 102 & 9.8 \\
\hline SEO is offered as the main but not only service & 108 & 10.3 \\
\hline SEO is one more service in their portfolio & 833 & 79.9 \\
\hline & 1,043 & 100.0 \\
\hline
\end{tabular}

Table 6. SEO companies by size

\begin{tabular}{|l|c|c|}
\cline { 2 - 3 } \multicolumn{1}{c|}{} & Frequency & Percentage \\
\hline Owner-operator & 216 & 20.7 \\
\hline Company with more than one person & 827 & 79.3 \\
\hline & 1,043 & 100.0 \\
\hline
\end{tabular}


Table 7. Cities with the most SEO companies and their density per inhabitant

\begin{tabular}{|l|c|c|c|}
\hline \multicolumn{1}{|c|}{ City } & $\begin{array}{c}\text { Number of SEO } \\
\text { companies }\end{array}$ & $\begin{array}{c}\text { Percentages of compa- } \\
\text { nies among all cities }\end{array}$ & $\begin{array}{c}\text { Density of SEO com- } \\
\text { panies per 100,000 } \\
\text { inhabitants }\end{array}$ \\
\hline Madrid & 132 & 11.3 & $3,223,334$ \\
\hline Barcelona & 79 & 6.8 & $1,620,343$ \\
\hline Valencia & 38 & 3.3 & 791,413 \\
\hline Zaragoza & 28 & 2.4 & 666,880 \\
\hline Alicante & 27 & 2.3 & 331,577 \\
\hline Málaga & 23 & 2.0 & 5.9 \\
\hline Seville & 23 & 2.0 & 6.1 \\
\hline Bilbao & 21 & 1.8 & 682,711 \\
\hline Granada & 20 & 1.7 & 345,821 \\
\hline Toledo & 19 & 1.6 & 232,208 \\
\hline
\end{tabular}

\section{Conclusions}

This study presents a cybermetric methodology that allows the creation of a universe of companies, as demonstrated for the case of the SEO industry in Spain. For this, an exploratory study is proposed with special emphasis on the design of the research, using a search engine as a source and the positioning indicator as a unit of measurement. This approach provides an overview of the industry, as well as presenting an innovative data capture design, based on the application of SEO techniques in the predominant search engine, Google, which is proposed as a solution to the limitations of the other sources selected. In this way, it provides a method to identify the companies with the best web positioning in Google in local searches.

As part of this study, the Clasificación Nacional de Actividades Económicas (CNAE) and professional associations were thus reviewed. However, although the CNAE is usually applied to determine the size of a given productive sector, it presents limitations if one wants to obtain deeper sight into a specific professional activity, as in the current case. Professional associations allow specialized and up-to-date observations of a specific sector, but this search did not identify any association that collects SEO companies in Spain, or a directory that may have been created within other asso-

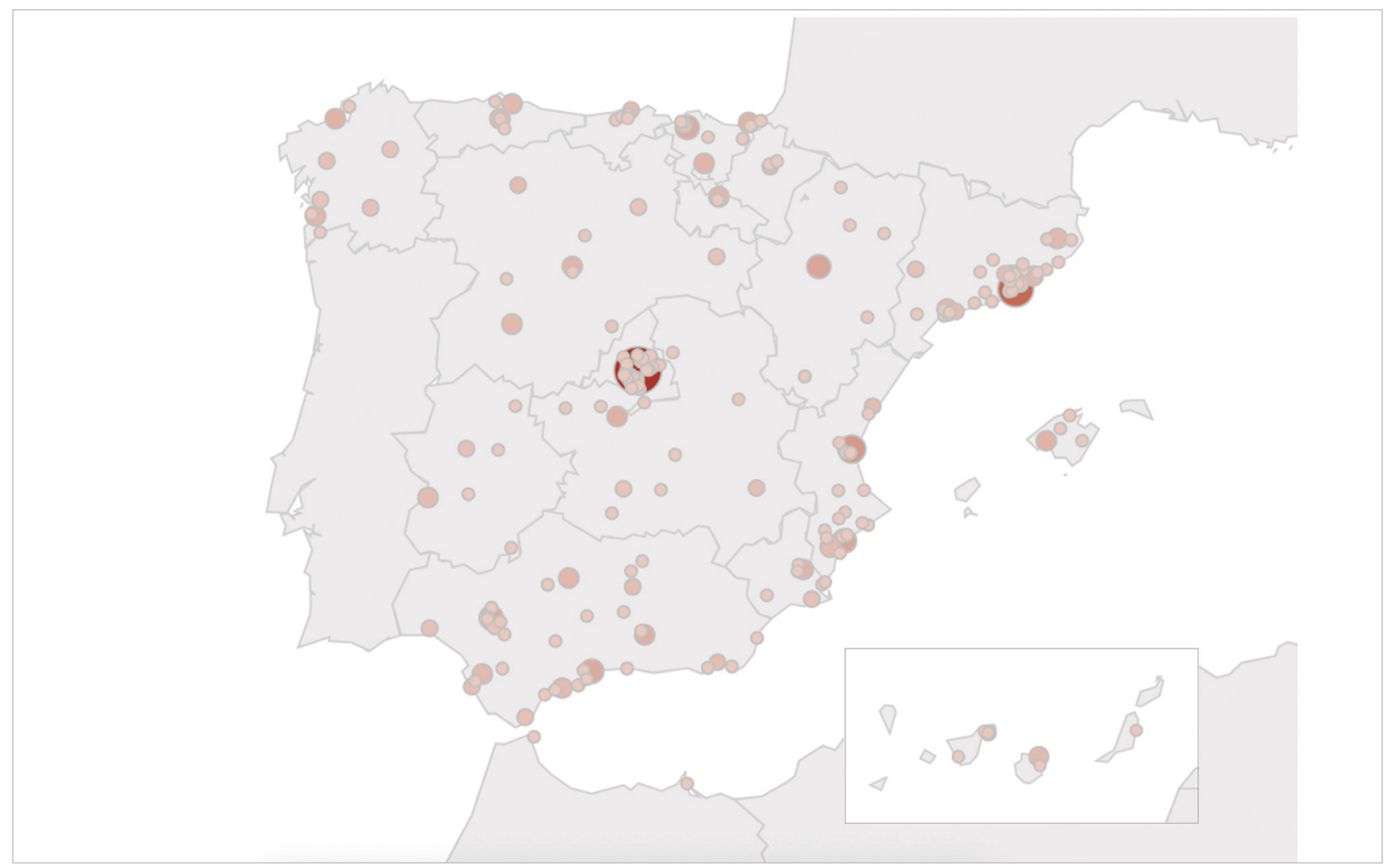

Graph 1. SEO distribution in Spain by city 
ciations with the approach attempted herein. In contrast, this analysis, on the one hand, presents a broader framework of how SEO companies are classified in the CNAE, in terms of both technical SEO and content SEO and, on the other, confirms the relationship between communication advertising and SEO-related functions in today's digital environment.

The strengths of this study include the methodological nature of the approach, using applied cybermetrics oriented towards institutions and companies (Orduña-Malea; Aguillo, 2014). The limitations arise from the very nature of the queries and source used, viz. the search engine. Although an attempt was made to eradicate biases resulting from geographic location, personalization, or fluctuation of the results, searches carried out from different devices or at different times could yield different results, either due to a significant change in the algorithm, the use of SEO techniques by the companies that make them rise in position, or the emergence or disappearance of any of them.

To address the first objective, we describe an information retrieval strategy that is designed and applied, to guarantee its reproducibility, while at the same time providing conclusive results. The proposal to use Google for the creation of a universe of SEO companies is understood as significant in this sector, since their activity is indeed carried out in search engines, thus detecting the best-positioned companies. A study of keywords was carried out, based on the volume of searches, using the methods of the discipline itself. Likewise, the entire country is covered through geolocated searches, with the most important cities in the country being included in the search strings as provincial capitals or because of the size of their population.

The data extracted from the application of this method, plus the queries of the websites found, address the second objective. The results from February 2019 reveal that the business sector corresponding to companies offering SEO services in Spain that are better positioned for local searches comprises 1,043 entities. The difference between the data extracted directly from the websites and the answers obtained a year later is $5 \%$.

Regarding their geographical distribution, it is concluded that companies offering SEO to third parties are present in practically all provinces of Spain, with Ávila being the only provincial capital that does not have any SEO companies positioned locally. Madrid, Barcelona, and Valencia, the most populous cities, are also those with the most SEO companies. Regarding the density of companies per inhabitant, among the ranking of cities with more SEO companies, Toledo stands out, with a much higher ratio than the others due to its much smaller population, and Alicante, which ranks fifth; despite not being one of the most populous capitals, it still has almost as many companies as the next ranked city, Zaragoza, with twice the population.

Regarding the profile, most of the companies are present in only one city, do not offer only SEO services, and have more than one employee. The fact that many of the companies that offer SEO do so together with other services suggests that they are mostly digital marketing or website creation agencies that offer a global strategy including SEO. Regarding size, the fraction of owner-operators exceeds $20 \%$, although it could be higher, since many independent professionals create a corporate website to make it look like a company, which can mean that one in four companies is an independent consultant, a figure that reflects the importance of micro-enterprises in this sector.

The ranking of the ten SEO companies best positioned in Google highlights that they are not always located in large capitals. It is also noteworthy that this list does not include any companies in Barcelona, the Spanish city ranked second in terms of the number of SEO companies.

The proportion of independent consultants in this ranking is $30 \%$, indicating that being a small business, in this case an owner-operator, is not a limitation on achieving better positioning. Alternatively, and perhaps precisely because of this, such small companies place greater emphasis on self-promotion to attract customers from the local area or using geo-positioning techniques compared with large companies, which can rely on other means such as reputation or recommendations.

The creation of this universe of the best-positioned SEO companies, the main result of the research, provides a starting point for deeper analysis to corroborate these conclusions and broaden knowledge about the internal structures of such companies, among other factors.

SEO is a sector in constant change, fundamentally subject to algorithm updates, and the evolution of users and technology. In this ecosystem, which is evolving with dizzying speed, professionals have to continually relearn the rules of the game, which although based on basic principles that remain constant over time, are subject to continual modification. Adaptation is vital for survival, which may result in the lack of continuum in the structure of companies in this sector, which itself is also conditioned by the very nature of the discipline.
Of companies that offer SEO, $20 \%$ do so exclusively as their main service 
Having established the universe of the best-positioned SEO companies in Spain, future lines of research focused on both quantitative and qualitative methods could provide a more complete snapshot and further knowledge about the actors in this market sector.

\section{References}

Adigital (2020). Asociación Española de la Economía Digital. https://www.adigital.org/quienes-somos

Álamo-Álvarez, Estrella (2010). Guía SEO. Comunicar contenidos y servicios a través de buscadores. Workshop Comunicar en Red.

https://slideplayer.es/slide/27164

Almind, Tomas C.; Ingwersen, Peter (1997). "Informetric analyses on the World Wide web. Methodological approaches to 'webometrics'”. Journal of documentation, v. 53, n. 4, pp. 404-426.

https://doi.org/10.1108/eum0000000007205

Arbildi-Larreina, Iñigo (2005). “Posicionamiento en buscadores: Una metodología práctica de optimización de sitios web". El profesional de la información, v. 14, n. 2, pp. 108-127.

http://elprofesionaldelainformacion.com/contenidos/2005/marzo/3.pdf

Arroyo-Vázquez, Natalia; Ortega-Priego, José-Luis; Pareja, Víctor; Prieto-Valverde, José-Antonio; Aguillo, Isidro F. (2005). "Cibermetría. Estado de la cuestión". 9as Jornadas españolas de documentación, Madrid.

http://eprints.rclis.org/8108/1/ArroyoEtAl_FESABID2005.pdf

Asociación de Agencias de Medios, AM (2020). Miembros.

http://www.agenciasdemedios.com/miembros-de-la-am

Asociación Española de Agencias de Comunicación Publicitaria, AEACP (2020). Socios.

https://www.linkedin.com/company/aeacp.-asociaci-n-espa-ola-de-agencias-de-comunicaci-n-publicitaria

Asociación para la Investigación en Medios de Comunicación, AIMC (2021). Evolución de usuarios. https://internet.aimc.es/index.html\#/main/evousers

Azzopardi, Leif; White, Ryen R.; Thomas, Paul; Craswell, Nick (2020). "Data-driven evaluation metrics for heterogeneous search engine result pages". In: CHIIR '20. Proceedings of the 2020 Conference on human information interaction and retrieval, pp. 213-222.

https://doi.org/10.1145/3343413.3377959

Bar-Ilan, Judith (1999). "Search engine results over time - a case study on search engine stability". Cybermetrics, v. 2, n. 1, paper 1. http://cybermetrics.cindoc.csic.es/articles/v2i1p1.pdf

Baye, Michael R.; De-los-Santos, Babur; Wildenbeest, Matthijs R. (2016). "Search engine optimization: What drives organictraffic to retail sites?". Journal of economics \& management strategy, v. 25 n. 1.

https://doi.org/10.1111/jems.12141

Björneborn, Lennart; Ingwersen, Peter (2001). "Perspectives on webometrics”. Scientometrics, v. 50, n. 1, pp. 65-82. https://doi.org/10.1023/A:1005642218907

Chen, Chen-Yuan; Shih, Bih-Yaw; Chen, Zih-Siang; Chen, Tsung-Hao (2011). "The exploration of internet marketing strategy by search engine optimization: A critical review and comparison". African journal of business management, v. $5, \mathrm{n}$. 12, pp. 4644-4649.

https://academicjournals.org/article/article1380550042_Chen\%20et\%20al.pdf

Chotikitpat, Kittisak; Nilsook, Prachyanun; Sodsee, Sunantha (2015). "Techniques for improving website rankings with search engine optimization (SEO)". Advanced science letters, v. 21, n. 10, pp. 3219-3224.

https://doi.org/10.1166/asl.2015.6503

Codina, Lluís (2004). "Posicionamiento web: Conceptos y ciclo de vida". Hipertext.Net, n. 2.

https://raco.cat/index.php/Hipertext/article/view/57793

Codina, Lluís; Gonzalo-Penela, Carlos; Pedraza-Jiménez, Rafael; Rovira, Cristòfol (2017). Posicionamiento web y medios de comunicación ciclo de vida de una campaña y factores SEO. Barcelona: Universitat Pompeu Fabra, Departament de Comunicació, p. 41 (Serie digital Digidoc. Proyecto comunicación interactiva).

http://doi.org/10.31009/DigiDoc.2019.inf23

Codina, Lluís; Lopezosa, Carlos (2019). Optimizar el SEO de contenidos mediante análisis asistido por ordenador: el software Yoast SEO. Guía de utilización para periodistas y comunicadores. Barcelona: Área de Formatos Digitales y Documentación. Facultad de Periodismo. Universitat Pompeu Fabra.

https://repositori.upf.edu/bitstream/handle/10230/42242/Codina_SEOperiodismo.pdf 
Cueto-Álvarez-de-Sotomayor, Luis; Soler-Herreros, Chimo; Entremonzaga-Ayuso, Raquel; Martínez, Eva; Carrasco, Antonio; Aguillo, Isidro F.; Fernández, Elena; Rodríguez-Artacho, Miguel; Barrantes, Dionisio; Espadas-Bardón, Javier; Ferreras-Marcos, Rufino; Albert, Jaime; Sanz-de-las-Heras, Jesús (2005). "Técnicas de análisis de posicionamiento". El profesional de la información, v. 14, n. 1, pp. 14-20.

http://profesionaldelainformacion.com/contenidos/2005/enero/2.pdf

Dean, Brian (2019). "We analyzed 5 million Google Search results. Here's what we learned about organic click through rate". Backlinko, 27 August.

https://backlinko.com/google-ctr-stats

Egri, Gokhan; Bayrak, Coskun (2014). "The role of search engine optimization on keeping the user on the site". Procedia computer science, v. 36, pp. 335-342.

https://doi.org/10.1016/j.procs.2014.09.102

Enge, Eric; Spencer, Stephan; Fishkin, Rand; Stricchiola, Jessie (2012). The art of SEO. Sebastopol, CA: O’Reilly Media. ISBN: 9781449304218

Evans, Michael P. (2007). “Analysing Google rankings through search engine optimization data”. Internet Research, v. 17, n. 1, pp. 21-37.

https://doi.org/10.1108/10662240710730470

Federación de Empresas de Publicidad y Comunicación, La Fede (2020). Socios.

https://www.lafede.es/listado-de-socios

Fernández, Rosa (2021a). "Cuota de mercado de los motores de búsqueda online usados desde ordenadores de sobremesa a nivel mundial de enero de 2012 a enero de 2020". Statista, 23 abril.

https://es.statista.com/estadisticas/634462/cuota-de-mercado-mundial-de-los-motores-de-busqueda

Fernández, Rosa (2021b). "Los buscadores online - Datos estadísticos". Statista, 29 septiembre.

https://es.statista.com/temas/3898/los-buscadores-online

Fortunato, Santo; Flammini, Alessandro; Menczer, Filippo; Vespignani, Alessandro (2005). "The egalitarian effect of search engines". PNAS, v. 103, n. 34, pp. 12684-12689.

https://doi.org/10.1073/pnas.0605525103

Gonzalo-Penela, Carlos (2004). "La selección de palabras clave para el posicionamiento en buscadores". Hipertext.net, n. 2.

https://www.raco.cat/index.php/Hipertext/article/view/57816

Gonzalo-Penela, Carlos (2015). Posicionamiento web y dinámicas de información en motores de búsqueda: Propuestas de análisis y estudio comparativo de visibilidad de contenidos digitales en el caso de procesos electorales. Tesis doctoral. Universidad Pompeu Fabra.

https://www.tdx.cat/handle/10803/292730

IAB Spain (2010). "El libro blanco de IAB. SEO: optimización de webs para buscadores". Cuadernos de comunicación interactiva, v. 11. Madrid: Ed. Edipo S.A.

IAB Spain (2020). Asociados.

https://iabspain.es/asociados

Iglesias-García, Mar; Codina, Lluís (2016). “Los cibermedios y la importancia estratégica del posicionamiento en buscadores (SEO)". Opción: Revista de ciencias humanas y sociales, n. 9, pp. 929-944.

http://hdl.handle.net/10045/72320

Ingwersen, Peter (1998). "The calculation of web impact factors". Journal of documentation, v. 54, n. 2, pp. $236-243$. https://doi.org/10.1108/eum0000000007167

Instituto Nacional de Estadística (2009). CNAE Clasificación nacional de actividades económicas. https://bit.ly/3iPAY5d

Instituto Nacional de Estadística (2018). Estadística del padrón continuo. Resultados.

https://bit.ly/3iOuLnE

Internet Live Stats (2021). Google search statistics.

https://www.internetlivestats.com/google-search-statistics

Killoran, John B. (2009). "Targeting an audience of robots: Search engines and the marketing of technical communication business websites". IEEE Transactions on professional communication, v. 52, n. 3, pp. 254-271.

https://doi.org/10.1109/TPC.2009.2025309 
Killoran, John B. (2010). "Writing for robots: Search engine optimization of technical communication business web sites". Technical communication, v. 57, n. 2, pp. 161-181.

https://www.jstor.org/stable/43094231

Kritzinger, Wouter; Weideman, Melius (2013). "Search engine optimization and pay-per-click marketing strategies". Journal of organizational computing and electronic commerce, v. 23, n. 3.

https://doi.org/10.1080/10919392.2013.808124

Krstić, Natasa (2019). "The relationship between website management and search engine optimisation". Megatrend revija, v. 16 n. 2, pp. 155-168.

https://doi.org/10.5937/MegRev1902155K

https://scindeks-clanci.ceon.rs/data/pdf/1820-3159/2019/1820-31591902155K.pdf

Larson, Ray (1996). "Bibliometrics of the world wide web: An exploratory analysis of the Structure of cyberspace". Conference paper.

http://hdl.handle.net/10150/106530

Lawrence, Steve; Giles, C. Lee (1998). “Searching the world wide web”. Science, v. 280, n. 5360, pp. 98-100.

https://doi.org/10.1126/science.280.5360.98

Lopezosa, Carlos; Codina, Lluís; Freixa, Pere (2018). "SEO y comunicación audiovisual: Análisis comparativo de portales de vídeo bajo demanda". DigiDoc-EPI, n. 3. Barcelona: Universitat Pompeu Fabra, Departamento de Comunicación, Ediciones Profesionales de la Información SL. ISBN: 9788409024315

https://doi.org/10.31235/osf.io/9v5zn

Lopezosa, Carlos; Codina, Lluís; Gonzalo-Penela, Carlos (2019). "SEO off page y construcción de enlaces: Estrategias generales y transmisión de autoridad en cibermedios". El profesional de la información, v. 28, n. 1, e280107.

https://doi.org/10.3145/epi.2019.ene.07

Maciá-Domene, Fernando (2016). Técnicas avanzadas de posicionamiento en buscadores. Madrid: Anaya Multimedia. ISBN: 9788441529632

Maciá-Domene, Fernando (2020). SEO avanzado. Casi todo lo que sé sobre posicionamiento web. Madrid: Anaya Multimedia. ISBN: 9788441541078

Marcos, Mari-Carmen; Codina, Lluís (2005). "Posicionamiento web: Conceptos y herramientas". El profesional de la información, v. 14, n. 2, pp. 84-99.

http://profesionaldelainformacion.com/contenidos/2005/marzo/1.pdf

Marcos, Mari-Carmen; Morales, Albert; Davradou, Eleni; López, Fernanda; Malvar, Paulo; Mayor, Agustí; Benmakhlouf, Hajar; Dwelle, Philip; Hernández, Pedro; Mesa, Bartolomé; Ortega, Mireia; Pérez, Juan Manuel; Renau, Irene; Serván, Isabel (2006). "Evaluación del posicionamiento web en sistemas de información terminológicos online". Hipertext.Net, n. 4.

https://www.raco.cat/index.php/Hipertext/article/view/57772

Marketing4Ecommerce (2020). Top 60: Las mejores agencias SEO de España según su propio trabajo SEO.

https://marketing4ecommerce.net/mejores-agencias-seo-espana-top/amp

Matošević, Goran (2015). "Measuring the utilization of on-page search engine optimization in selected domain". Journal of information and organizational sciences, v. 39, n. 2, pp. 199-207.

https://hrcak.srce.hr/149625

Mavridis, Themistoklis; Symeonidis, Andreas L. (2015). "Identifying valid search engine ranking factors in a web 2.0 and web 3.0 context for building efficient SEO mechanisms". Engineering applications of artificial intelligence, v. 41, pp. 75-91.

https://doi.org/10.1016/j.engappai.2015.02.002

McCue, T. J. (2018), "SEO industry approaching $\$ 80$ billion but all you want is more web traffic". Forbes, 30 July. https://www.forbes.com/sites/tjmccue/2018/07/30/seo-industry-approaching-80-billion-but-all-you-want-is-moreweb-traffic/?sh=10b6dcac7337

Mettrop, Wouter; Nieuwenhuysen, Paul (2001). "Internet search engines - fluctuations in document accessibility". Journal of documentation, v. 57, n. 5, pp. 623-651.

https://doi.org/10.1108/EUM0000000007096

Miguel-San Emeterio, Begoña (2018). Las competencias digitales en los grados en periodismo, publicidad y relaciones públicas y comunicación audiovisual en la universidad. El caso de la Comunidad de Madrid. Tesis doctoral. Universidad Complutense de Madrid.

https://eprints.ucm.es/id/eprint/50690 
Moráguez-Bergues, Mercedes; Perurena-Cancio, Lilliam (2014). “Propuesta de factores a considerar en el posicionamiento de los sitios web de salud". Gecontec: Revista internacional de gestión del conocimiento y la tecnología, v. 2 , n.1. https://ssrn.com/abstract=2436432

Morato-Lara, Jorge; Sánchez-Cuadrado, Sonia; Cruz-Valiente, María (2005). “Análisis de estrategias de posicionamiento en relación con la relevancia documental”. El profesional de la información, v. 14, n. 1, pp. 21-29.

http://profesionaldelainformacion.com/contenidos/2005/enero/3.pdf

Morato-Lara, Jorge; Sánchez-Cuadrado, Sonia; Moreno-Pelayo, Valentín; Moreiro-González, José-Antonio (2013). "Evolución de los factores de posicionamiento web y adaptación de las herramientas de optimización". Revista española de documentación científica, v. 36, n. 3.

https://doi.org/10.3989/redc.2013.3.956

Moreno-Pelayo, Valentín (2005). "Interacción entre medidas de popularidad en el posicionamiento web". El profesional de la información, v. 14, n. 2, pp. 100-107.

http://profesionaldelainformacion.com/contenidos/2005/marzo/2.pdf

Orduña-Malea, Enrique; Aguillo, Isidro F. (2014). Cibermetría: midiendo el espacio red. Barcelona: Editorial UOC, Colección EPI-Scholar, n. 1.

http://profesionaldelainformacion.com/EPIScholar/cibermetria-espacio-red.html

Özkan, Baris; Özceylan, Eren; Kabak, Mehmet; Dağdeviren, Metin (2020). "Evaluating the websites of academic departments through SEO criteria: A hesitant fuzzy linguistic MCDM approach". Artificial intelligence review, v. 53, n. 2, pp. 875-905.

https://doi.org/10.1007/s10462-019-09681-z

Pack-Sheffield, Jenna (2020). "Search engine optimization and business communication instruction: Interviews with experts". Business and professional communication quarterly, v. 83, n. 2.

https://doi.org/10.1177/2329490619890335

Papí-Gálvez, Natalia; López-Berna, Sonia (2011). “Medios online y publicidad. perfiles profesionales en educación superior". Vivat academia, n. 117, pp. 672-700.

https://doi.org/10.15178/va.2011.117E.672-700

Pérez-Montoro, Mario (2016). “Navegabilidad y SEO en entornos web”. Hipertext.net, n. 14.

https://doi.org/10.2436/20.8050.01.29

Rousseau, Ronald (1999). "Daily time series of common single word searches in AltaVista and NorthernLight". Cybermetrics, v. 2/3, n. 1.

http://www.cindoc.csic.es/cybermetrics/articles/v2i1p2.html

Rovira, Cristòfol (2008). “Vigilancia tecnológica e inteligencia competitiva para SEM-SEO”. Hipertext.net, n. 6. https://www.raco.cat/index.php/Hipertext/article/view/131952

Rovira, Cristòfol; Codina, Lluís; Marcos, Mari-Carmen (2009). “Cómo contratar un servicio de posicionamiento web”. El profesional de la información, v. 18, n. 2, pp. 229-236.

http://doi.org/10.3145/epi.2009.mar.14

Rovira, Cristòfol; Fernández-Cavia, José; Pedraza-Jiménez, Rafael; Huertas-Roig, Assumpció (2010). “Posicionamiento en buscadores de las webs oficiales de capitales de provincia españolas". El profesional de la información, v. 19, n. 3, pp. 277-284.

http://doi.org/10.3145/epi.2010.may.08

Ruiz-Olabuénaga, José-Ignacio; Aristegui, Iratxe; Melgosa, Leire (1998). Cómo elaborar un proyecto de investigación social. Bilbao: Universidad de Deusto, 138 pp. ISBN: 8474855470

Sabaté-Garriga, Ferran; Berbegal, Jasmina; Consolación-Segura, Carolina; Cañabate-Carmona, Antonio (2009). "La utilización de estrategias SEO en el sector de la venta de libros". Intangible capital, v. 5, n. 3, pp. 321-346.

https://doi.org/10.3926/ic.129

Serrano-Cobos, Jorge (2014). "El profesional de la información como gestor de eCommerce". Anuario ThinkEPI, v. 8, pp. 70-72.

https://recyt.fecyt.es/index.php/ThinkEPI/article/view/29556/15665

Serrano-Cobos, Jorge (2015). SEO: Introducción a la disciplina del posicionamiento en buscadores. Barcelona: Editorial UOC, Colección EPI-Scholar, n. 3, 200 pp. ISBN: 9788490649565

Snyder, Herber; Rosenbaum, Howard (1999). "Can search engines be used as tools for web-link analysis? A critical view". Journal of documentation, v. 55, n. 4, pp. 375-384.

https://doi.org/10.1108/EUM0000000007151 
Soler-del-Pozo, Julio (2012). “Aproximación al estudio del posicionamiento en buscadores con WordPress: Elementos internos favorecedores". Cuadernos de gestión de información, v. 2, pp. 85-104.

http://hdl.handle.net/10201/50975

Solis, Aleyda (2017). SEO. claves esenciales. Madrid: Anaya Multimedia. ISBN: 9788441537286

Soltero-Domingo, Francisco-José; Bodas-Sagi, Diego-José (2005). “Clasificadores inductivos para el posicionamiento web". El profesional de la información, v. 14, n. 1, pp. 4-13.

http://profesionaldelainformacion.com/contenidos/2005/enero/1.pdf

Su, Ao-Jan; Hu, Y. Charlye; Kuzmanovic, Aleksandar; Koh, Cheng-Kok (2010). "How to improve your Google ranking: Myths and reality". In: IEEE/WIC/ACM International conference on web intelligence and intelligent agent technology, pp. 50-57.

https://doi.org/10.1109/WI-IAT.2010.195

Thelwall, Mike (2009). Introduction to webometrics: quantitative web research for the social sciences. New York, NY: Morgan \& Claypool.

https://doi.org/10.2200/S00176ED1V01Y200903ICR004

Thelwall, Mike (2010). "Webometrics: emergent or doomed?". Information research, v. 15, n. 4. http://InformationR.net/ir/15-4/colis713.html

Thelwall, Mike; Wilkinson, David (2004). "Finding similar academic Web sites with links, bibliometric couplings and colinks". Information processing and management, v. 40, n. 3, pp. 515-526.

https://doi.org/10.1016/S0306-4573(03)00042-6

Valdés-Morris, Mirta (2007). "Algunas consideraciones sobre el posicionamiento web". Revista cubana de información en ciencias de la salud, v. 15, n. 5.

http://scielo.s/d.cu/pdf/aci/v15n5/aci05507.pdf

Vállez, Mari; Rovira, Cristòfol; Codina, Lluís; Pedraza-Jiménez, Rafael (2010). "Procedimientos para la extracción de palabras clave de páginas web basados en criterios de posicionamiento en buscadores". Hipertext.net, n. 8.

https://www.upf.edu/hipertextnet/numero-8/extraccion_keywords.html

Vaughan, Liwen; Zhang, Yanjun (2007). "Equal representation by search engines? A comparison of websites across countries and domains". Journal of computer-mediated communication, v. 12, n. 3, pp. 888-909.

https://doi.org/10.1111/j.1083-6101.2007.00355.x

Wahba, Walaa Z.; Barhoom, Tawfiq S. (2019). "SEO: Improve website ranking based on competitors analysis". International research journal of engineering and technology (IRJET), v. 6, n. 8.

https://www.irjet.net/archives/V6/i8/IRJET-V6/8153.pdf

Weideman, Melius (2009). Website visibility: The theory and practice of improving rankings. Oxford: Elsevier. ISBN: 978 1843344735

Zakon, Robert H. (2003). “Hobbes' internet timeline v6.0”. http://www.zakon.org/robert/internet/timeline

Zhang, Jin; Dimitroff, Alexandra (2005). "The impact of webpage content characteristics on webpage visibility in search engine results (part I)". Information processing \& management, v. 41, n. 3, pp. 665-690. https://doi.org/10.1016/j.ipm.2003.12.001

Zhang, Sonya; Cabage, Neal (2017). "Search engine optimization: Comparison of link building and social sharing". Journal of computer information systems, v. 57, n. 2, pp. 148-159.

https://doi.org/10.1080/08874417.2016.1183447

Zhu, Cen; Wu, Guixing (2011). "Research and analysis of search engine optimization factors based on reverse engineering". In: Third international conference on multimedia information networking and security, pp. 225-228.

https://doi.org/10.1109/MINES.2011.99 


\section{Annexes}

\section{Annex 1}

Cities and their corresponding UULE codes or latitude and longitude

\begin{tabular}{|c|c|c|}
\hline $\begin{array}{c}\text { Size } \\
\text { (population) }\end{array}$ & $\begin{array}{l}\text { City name used } \\
\text { in the search }\end{array}$ & UULE code or longitude and latitude of the city \\
\hline $3,223,334$ & Madrid & w+CAIQIClgTWFkcmlkLENvbW11 bml0eSBvZiBNYWRyaWQsU3BhaW4 \\
\hline $1,620,343$ & Barcelona & w+CAIQICIZQmFyY2Vsb25hLENhdGFsb25pYSxTcGFpbg \\
\hline 791,413 & Valencia & w+CAIQICliVmFsZW5jaWEsVmFsZW5jaWFulENvbW11bml0eSxTcGFpbg \\
\hline 688,711 & Seville & w+CAIQICIXU2V2aWxsZSxBbmRhbHVzaWEsU3BhaW4 \\
\hline 666,880 & Zaragoza & w+CAIQICIVWmFyYWdvemEsQXJhZ29uLFNwYWlu \\
\hline 571,026 & Málaga & w+CAIQICIWTWFsYWdhLEFuZGFsdXNpYSxTcGFpbg \\
\hline 447,182 & Murcia & w+CAIQICIdTXVyY2IhLFJIZ2lvbiBvZiBNdXJjaWEsU3BhaW4 \\
\hline 409,661 & Mallorca & w+CAIQICloUGFsbWEgZGUgTWFsbG9yY2EsQmFsZWFyaWMgSXNsYW5kcyxTcGFpbg \\
\hline 378,517 & Las Palmas & w+CAIQICIvTGFzIFBhbG1hcyBkZSBHcmFulENhbmFyaWEsQ2FuYXJ5IElzbGFuZHMsU3BhaW4 \\
\hline 345,821 & Bilbao & w+CAIQIClbQmlsYmFvLEJhc3F1ZSBDb3VudHJ5LFNwYWlu \\
\hline 331,577 & Alicante & w+CAIQICliQWxpY2FudGUsVmFsZW5jaWFulENvbW11 bml0eSxTcGFpbg \\
\hline 325,708 & Córdoba & w+CAIQICIXQ29yZG9iYSxBbmRhbHVzaWEsU3BhaW4 \\
\hline 298,866 & Valladolid & w+CAIQICIhVmFsbGFkb2xpZCxDYXN0aWxIIGFuZCBMZW9uLFNwYWlu \\
\hline 249,176 & Vitoria & w+CAIQICIkVml0b3JpYS1HYXNOZWI6LEJhc3F1ZSBDb3VudHJ5LFNwYWlu \\
\hline 244,850 & A Coruña & w+CAIQICIWQSBDb3J1bmEsR2FsaWNpYSxTcGFpbg \\
\hline 232,208 & Granada & w+CAIQICIXR3JhbmFkYSxBbmRhbHVzaWEsU3BhaW4 \\
\hline 220,020 & Oviedo & w+CAIQICIVT3ZpZWRvLEFzdHVyaWFzLFNwYWlu \\
\hline 204,856 & Tenerife & w+CAIQICIrU2FudGEgQ3J1 eiBkZSBUZW5IcmlmZSxDYW5hcnkgSXNsYW5kcyxTcGFpbg \\
\hline 199,066 & Pamplona & w+CAIQICIWUGFtcGxvbmEsTmF2YXJyZSxTcGFpbg \\
\hline 196,851 & Almería & w+CAIQICIXQWxtZXJpYSxBbmRhbHVzaWEsU3BhaW4 \\
\hline 186,665 & San Sebastián & w+CAIQICliU2FulFNIYmFzdGIhbixCYXNxdWUgQ291bnRyeSxTcGFpbg \\
\hline 175,921 & Burgos & w+CAIQICldQnVyZ29zLENhc3RpbGUgYW5kIExlb24sU3BhaW4 \\
\hline 173,050 & Albacete & w+CAIQIClgQWxiYWNIdGUsQ2FzdGIsZS1MYSBNYW5jaGEsU3BhaW4 \\
\hline 172,144 & Santander & w+CAIQICIZU2FudGFuZGVyLENhbnRhYnJpYSxTcGFpbg \\
\hline 170,888 & Castellón & w+CAIQICIVQ2FzdGVsbG9ulGRIIGxhIFBsYW5hLFZhbGVuY2lhbiBDb21tdW5pdHksU3BhaW4 \\
\hline 151,113 & Logroño & w+CAIQICIWTG9ncm9ubyxMYSBSaW9qYSxTcGFpbg \\
\hline 150,530 & Badajoz & w+CAIQICIZQmFkYWpveixFeHRyZW1hZHVyYSxTcGFpbg \\
\hline 144,258 & Huelva & w+CAIQICIWSHVIbHZhLEFuZGFsdXNpYSxTcGFpbg \\
\hline 143,978 & Salamanca & w+CAIQIClgU2FsYW1hbmNhLENhc3RpbGUgYW5kIExlb24sU3BhaW4 \\
\hline 137,856 & Lleida & w+CAIQICIWTGxlaWRhLENhdGFsb25pYSxTcGFpbg \\
\hline 132,299 & Tarragona & w+CAIQICIZVGFycmFnb25hLENhdGFsb25pYSxTcGFpbg \\
\hline 124,772 & León & w+CAIQICIbTGVvbixDYXNOaWxlIGFuZCBMZW9uLFNwYWlu \\
\hline 116,979 & Cádiz & w+CAIQICIVQ2FkaXosQW5kYWx1c2lhLFNwYWlu \\
\hline 113,457 & Jaén & w+CAIQICIUSmFlbixBbmRhbHVzaWEsU3BhaW4 \\
\hline 105,505 & Ourense & w+CAIQICIVT3VyZW5zZSxHYWxpY2lhLFNwYWlu \\
\hline 100,266 & Girona & w+CAIQICIWR2lyb25hLENhdGFsb25pYSxTcGFpbg \\
\hline 98,025 & Lugo & w+CAIQICISTHVnbyxHYWxpY2lhLFNwYWlu \\
\hline 96,405 & Santiago & w+CAIQICIkU2FudGIhZ28gZGUgQ29tcG9zdGVsYSxHYWxpY2lhLFNwYWlu \\
\hline 96,098 & Cáceres & Latitude: 39.4282320 . Longitude: -6.4378180 \\
\hline 86,384 & Melilla & w+CAIQICIVTWVsaWxsYSxNZWxpbGxhLFNwYWlu \\
\hline 85,144 & Ceuta & w+CAIQICIRQ2V1dGEsQ2V1dGEsU3BhaW4 \\
\hline 84,910 & Guadalajara & w+CAIQICljR3VhZGFsYWphcmEsQ2FzdGIsZS1MYSBNYW5jaGEsU3BhaW4 \\
\hline 84,282 & Toledo & w+CAIQICleVG9sZWRvLENhc3RpbGUtTGEgTWFuY2hhLFNwYWlu \\
\hline 82,802 & Pontevedra & w+CAIQICIYUG9udGV2ZWRyYSxHYWxpY2IhLFNwYWlu \\
\hline 78,629 & Palencia & Latitude: 42.0125 . Longitude: -4.53117 \\
\hline 74,743 & Ciudad Real & w+CAIQICIjQ211ZGFkIFJIYWwsQ2FzdGIsZS1MYSBNYW5jaGEsU3BhaW4 \\
\hline
\end{tabular}




\begin{tabular}{|c|c|c|}
\hline $\begin{array}{c}\text { Size } \\
\text { (population) }\end{array}$ & $\begin{array}{l}\text { City name used } \\
\text { in the search }\end{array}$ & UULE code or longitude and latitude of the city \\
\hline 61,827 & Zamora & Latitude: 41.5063300 . Longitude: -5.7445600 \\
\hline 59,392 & Mérida & w+CAIQICIYTWVyaWRhLEV4dHJlbWFkdXJhLFNwYWlu \\
\hline 57,697 & Ávila & w+CAIQICIfQXZpbGHigl4sQ2FzdGIsZSBhbmQgTGVvbixTcGFpbg \\
\hline 54,898 & Cuenca & w+CAIQICleQ3VlbmNhLENhc3RpbGUtTGEgTWFuY2hhLFNwYWlu \\
\hline 52,463 & Huesca & Latitude: 42.1483775 . Longitude: -0.4125338. \\
\hline 51,683 & Segovia & w+CAIQICleU2Vnb3ZpYSxDYXN0aWx\|IGFuZCBMZW9uLFNwYWlu \\
\hline 39,112 & Soria & w+CAIQIClcU29yaWEsQ2FzdGIsZSBhbmQgTGVvbixTcGFpbg \\
\hline 35,691 & Teruel & Latitude: 40.3456000 . Longitude: -1.1064600. \\
\hline 293,642 & Vigo & w+CAIQICISVmInbyxHYWxpY2lhLFNwYWlu \\
\hline 271,843 & Gijón & w+CAIQICIUR2lqb24sQXN0dXJpYXMsU3BhaW4 \\
\hline 261,068 & Hospitalet de LI. & w+CAIQICIpTCdlb3NwaXRhbGV0IGRIIExsb2JyZWdhdCxDYXRhbG9uaWEsU3BhaW4 \\
\hline 230,625 & Elche & w+CAIQICIpTCdlb3NwaXRhbGV0IGRIIExsb2JyZWdhdCxDYXRhbG9uaWEsU3BhaW4 \\
\hline 218,535 & Terrassa & w+CAIQICIYVGVycmFzc2EsQ2F0YWxvbmlhLFNwYWlu \\
\hline 217,741 & Badalona & w+CAIQICIYQmFkYWxvbmEsQ2F0YWxvbmlhLFNwYWlu \\
\hline 213,943 & Cartagena & w+CAIQIClgQ2FydGFnZW5hLFJIZ2IvbiBvZiBNdXJjaWEsU3BhaW4 \\
\hline 212,879 & Jerez & Latitude: 36.6866. Longitude: -6.13717. \\
\hline 211,734 & Sabadell & w+CAIQICIYU2FiYWRIbGwsQ2FoYWxvbmlhLFNwYWlu \\
\hline 207,095 & Móstoles & w+CAIQICliTW9zdG9sZXMsQ29tbXVuaXR5IG9mIE1hZHJpZCXTcGFpbg \\
\hline 193,751 & Alcalá & w+CAIQICIrQWxjYWxhIGRIIEhlbmFyZXMsQ29tbXVuaXR5IG9mIE1hZHJpZCxTcGFpbg \\
\hline 193,586 & Fuenlabrada & Latitude: 40.2839 . Longitude: -3.80033. \\
\hline 188,425 & Leganés & w+CAIQICIhTGVnYW5IcyxDb21tdW5pdHkgb2YgTWFkcmlkLFNwYWlu \\
\hline 180,747 & Getafe & w+CAIQICIgR2V0YWZILENvbW11bml0eSBvZiBNYWRyaWQsU3BhaW4 \\
\hline 169,502 & Alcorcón & w+CAIQICliQWxjb3Jjb24sQ29tbXVuaXR5IG9mIE1hZHJpZCxTcGFpbg \\
\hline 155,549 & La Laguna & w+CAIQIClvU2FulENyaXN0b2JhbCBkZSBMYSBMYWd1 bmEsQ2FuYXJ5IElzbGFuZHMsU3BhaW4 \\
\hline 141,463 & Marbella & w+CAIQICIYTWFyYmVsbGEsQW5kYWx1c2lhLFNwYWlu \\
\hline 133,168 & Dos Hermanas & Latitude: 37.2521681 . Longitude: -5.9598480. \\
\hline 129,729 & Torrejón & w+CAIQICIrVG9ycmVqb24gZGUgQXJkb3osQ29tbXVuaXR5IG9mIE1hZHJpZCXTcGFpbg \\
\hline 128,256 & Parla & Latitude: 40.2337784 . Longitude: -3.7720945. \\
\hline 126,988 & Mataró & w+CAIQICIWTWFOYXJvLENhdGFsb25pYSxTcGFpbg \\
\hline 121,414 & Algeciras & w+CAIQICIZQWxnZWNpcmFzLEFuZGFsdXNpYSxTcGFpbg \\
\hline 118,821 & Santa Coloma & Latitude: 41.4445879 . Longitude: 2.2103217. \\
\hline 116,037 & Alcobendas & w+CAIQICIkQWxjb2JlbmRhcyxDb21tdW5pdHkgb2YgTWFkcmlkLFNwYWlu \\
\hline 103,477 & Reus & Latitude: 41.15. Longitude: 1.1167. \\
\hline 102,424 & Telde & Latitude: 27.9777969. Longitude: -15.413667. \\
\hline 100,435 & Baracaldo & Latitude: 43.2975263. Longitude: -2.9862213. \\
\hline
\end{tabular}

.Source: census data from the INE and the search carried out in this work

\section{Annex 2}

Ranking of cities by number of best locally positioned SEO companies.

\begin{tabular}{|l|c|}
\hline \multicolumn{1}{|c|}{ Cities where the webs of the best locally positioned SEO companies are found } & $\begin{array}{c}\text { Number of SEO } \\
\text { companies }\end{array}$ \\
\hline Madrid & 132 \\
\hline Barcelona & 79 \\
\hline Valencia & 38 \\
\hline Zaragoza & 28 \\
\hline Alicante & 27 \\
\hline Málaga, Sevilla & 23 \\
\hline Bilbao & 21 \\
\hline
\end{tabular}




\begin{tabular}{|c|c|}
\hline Cities where the webs of the best locally positioned SEO companies are found & $\begin{array}{c}\text { Number of SEO } \\
\text { companies }\end{array}$ \\
\hline Granada & 20 \\
\hline Toledo & 19 \\
\hline Palma de Mallorca & 18 \\
\hline A Coruña, Donostia - San Sebastián, Murcia. & 17 \\
\hline Valladolid, Vitoria-Gasteiz. & 16 \\
\hline Córdoba,Vigo, Logroño. & 15 \\
\hline Gijón, Girona, Mataró, Reus, Salamanca. & 14 \\
\hline Jerez de la Frontera, Sabadell, Las Palmas de Gran Canaria, Oviedo. & 13 \\
\hline Badajoz, Elche, Marbella. & 12 \\
\hline Almería, Castellón, León, Pamplona, Santander, Terrassa. & 11 \\
\hline Tarragona & 10 \\
\hline Albacete, Cádiz, Jaén, Santa Cruz de Tenerife. & 9 \\
\hline Algeciras, Cartagena, Lleida, Santiago de Compostela. & 8 \\
\hline Cáceres, Huelva, Ourense. & 7 \\
\hline Fuenlabrada, Soria. & 6 \\
\hline Alcobendas, Alcorcón, Badalona, Barakaldo, Burgos, Ciudad Real, Dos Hermanas, Getafe, Lugo, Parla, Pontevedra. & 5 \\
\hline Alcalá de Henares, Cuenca. & 4 \\
\hline Alcalá de Guadaíra, Huesca, Leganés, Palencia, San Cristóbal de la Laguna, Segovia, Torrejón de Ardoz, Valdemoro. & 3 \\
\hline $\begin{array}{l}\text { Alfafar, Avilés, El Vendrell, Esplugues de Llobregat, Estepona, Gandía, Guadalajara, La Orotava, Los Corrales, Lucena, } \\
\text { Molina de Segura, Móstoles, Navarra, Pollença, San Fernando de Henares, San Vicente del Raspeig, Santa Coloma de } \\
\text { Gramenet, Teruel, Torrelavega, Torrelodones, Torrent, Vilafranca del Penedès, Vizcaya. }\end{array}$ & 2 \\
\hline $\begin{array}{l}\text { Abadiano, Adeje, Albolote, Alcalá del Río, Alcalá la Real, Alcantarilla, Alcañiz, Alcoy, Algete, Álora, Aranjuez, Arcos de } \\
\text { la Frontera, Artica, Astigarraga, Azuaga, Barbastro, Barcenilla de Piélagos, Benetússer, Valencia, Benidorm, Boadilla del } \\
\text { Monte, Bonmatí, Cabo de Gata, Cambrils, Campanillas, Campo de Criptana, Canals, Cangas do Morrazo, Castilleja de } \\
\text { Guzmán, Cee, Ceuta, Cornellà de Llobregat, Coslada, El Puerto de Santa María. Cádiz, Elda, Finestrat, Fuengirola, Gines, } \\
\text { Granollers, Hospitalet de Llobregat, Ibarra, Ibi, Igualada, Ilurdotz, Irún, Jaca, El Rosario, La Bisbal d'Empordà, La Garriga, } \\
\text { Laguna de Duero, Lardero, Las Rozas, Leioa, Les Alqueries, Linares, Llanera, Lloret de Mar, Lloseta, Lorca, Manacor, } \\
\text { Manresa, Melilla, Membrilla, Mengíbar, Mérida, Mieres, Mijas Costa, Mojácar, Mora D'Ebre, Muchamiel, Narón, Nerja, No- } \\
\text { velda, Pinto, Polinyà, Posadas, Pozuelo de Alarcón, Premia de Mar, Puertollano, Revilla de Camargo, Ribarroja del Turia, } \\
\text { Riudoms, Roquetas de Mar, Salou, San Javier, San Pedro de Alcántara, San Pedro del Pinatar, San Sebastián de los Reyes, } \\
\text { Sant Cugat del Vallès, Sant Quirze del Vallès, Sant Vicenç de Montalt, Santa Pola, Santurce, Sitges, Talavera de la Reina, } \\
\text { Talayuela, Telde, Tolosa, Guipúzcoa, Tomares, Torrejón de la Calzada, Torremolinos, Torrijos, Tres Cantos, Madrid, Trujillo, } \\
\text { Tui, Utrera, Vila-seca, Villaescusa, Villaviciosa de Odón, Zamora. }\end{array}$ & 1 \\
\hline Not specified & 31 \\
\hline Total locations ( 1,043 headquarters +121 branches) & 1,164 \\
\hline
\end{tabular}

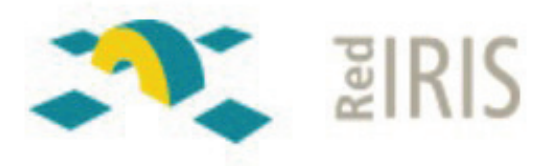

\section{COMUNICACIÓN}

\section{https://www.rediris.es/list/info/comunicacion.htm/}

Comunicación es una lista de distribución en castellano para debatir y estar al día sobre teoría de la comunicación, comunicación política, comunicación industrial, relaciones públicas, comunicación audiovisual y multimedia, radio y televisión, cinematografía, periodismo, periodismo de datos, divulgación de la ciencia, medios y cibermedios, redes sociales... y todos los aspectos relacionados con la COMUNICACIÓN.

Empezó a funcionar en enero de 2017 y está alojada en el servicio de listas de RedIRIS, desde donde es posible consultar sus archivos:

https://listserv.rediris.es/cgi-bin/wa?AO=COMUNICACION

La lista cuenta con 2 moderadores que permanentemente filtran los mensajes para evitar spam, mensajes inapropiados, anuncios, mensajes repetidos, etc.:

Isabel Olea (EPI, León)
Tomàs Baiget (EPI, Barcelona)

Puedes suscribirte a Comunicación en:

https://listserv.rediris.es/cgi-bin/wa?SUBED1=COMUNICACION\&A=1 